\title{
Effect of process variables on the physicochemical and rheological properties of yogurt
}

\section{Efecto de las variables de proceso sobre las propiedades fisicoquímicas y reológicas de yogur}

Héctor J. Paz-Díaz; ${ }^{1}$ Lia Z. Mora-Vergara²; Cristian E. Navarro-Arana ${ }^{3}$; Alba Sofia Navarro; Mónica María Pacheco-Valderrama ${ }^{5}$

${ }^{1}$ Agroindustrial Engineer, Spc. Workplace Health and Safety, Instituto Universitario de la Paz, UNIPAZ. Barrancabermeja - Santander, Colombia; e-mail: hector.paz@unipaz.edu.co; (D) https://orcid.org/0000-0002-3278-7667

${ }^{2}$ Biological Engineer, Spc. Environmental Sanitation Engineering, Instituto Universitario de la Paz, UNIPAZ. Barrancabermeja - Santander, Colombia; e-mail: lia.mora@unipaz.edu.co; ${ }^{(D)}$ https://orcid.org/0000-0003-0300-2813

${ }^{3}$ B.A. in English Language Teaching, Instituto Universitario de la Paz, UNIPAZ. Barrancabermeja - Santander, Colombia; e-mail: edgardo.navarro@unipaz.edu.co; (iD) https://orcid.org/0000-0002-1090-2839

${ }^{4}$ Chemist, Ph.D. Centro de Investigación y Desarrollo en Criotecnología de Alimentos, CIDCA, Universidad Nacional de La Plata, Argentina; e-mail: albanavarro@ conicet.gov.ar; ${ }^{10}$ http://orcid.org/0000-0002-7180-3551

${ }^{5}$ Food Engineer, M.Sc. Food Science and Technology, Instituto Universitario de la Paz, UNIPAZ. Barrancabermeja - Santander, Colombia; e-mail: monica.pacheco@unipaz.edu.co, ${ }^{\text {iD }}$ https://orcid.org/0000-0003-2051-4589

How to cite: Paz-Díaz, H.J.; Mora-Vergara, L.Z.; Navarro-Arana, C.E.; Navarro, A.S.; Pacheco-Valderrama, M.M. 2021. Effect of process variables on the physicochemical and rheological properties of yogurt. Rev. U.D.C.A Act. \& Div. Cient. 24(1):e1922. http://doi. org/10.31910/rudca.v24.n1.2021.1922

Open access article published by Revista U.D.C.A Actualidad \& Divulgación Científica, under Creative Commons License CC BY-NC 4.0

Official publication of the Universidad de Ciencias Aplicadas y Ambientales U.D.C.A, University, Accredited as a High-Quality Institution by the Colombian Ministry of Education.

Received: May 18, 2020 Accepted: April 16, 2021 Edited by: Rita María Ávila G. de Hernández

\begin{abstract}
In this research, the effect of the lactic starter culture, the fermentation time, the incubation temperature and the percentage of fat on the firmness and consistency of a fermented milk drink was evaluated through physicochemical characteristics of total acidity, $\mathrm{pH}$, syneresis and flow behavior. The purpose was to find the best formulation that extends the shelf life of yogurt, leading to an improvement in the manufacturing process of a local dairy company in Barrancabermeja (Santander, Colombia). Quality criteria were evaluated by means of the percentage of acidity and $\mathrm{pH}$ of the yogurt, as well as its syneresis and rheological parameters during a storage time of 24 hours and 7 days in refrigeration. Acceptable
\end{abstract}

quality parameters were obtained for the yogurt prepared with an inoculum concentration of $2 \%$, an incubation temperature of $40^{\circ} \mathrm{C}$ and an incubation time of 150 minutes. In addition, better properties of firmness and consistency were found, with absence of syneresis and viscosity in the accepted range, for this dairy product.

Keywords: Acidity; Lactic culture; Syneresis; Viscosity; Yogurt.

\section{RESUMEN}

En esta investigación, se evaluó el efecto del cultivo iniciador láctico, el tiempo de fermentación, la temperatura de incubación y el porcentaje de grasa en la firmeza y consistencia de una bebida 
de leche fermentada, a través de las características fisicoquímicas de acidez total, $\mathrm{pH}$, sinéresis y comportamiento de flujo. El propósito fue encontrar la mejor formulación que extienda la vida útil del yogur, lo que lleva a un perfeccionamiento del proceso de fabricación de una empresa local de productos lácteos en Barrancabermeja (Santander, Colombia). Se evaluaron criterios de calidad por medio del porcentaje de acidez y $\mathrm{pH}$ del yogurt, así como su sinéresis y parámetros reológicos, durante un tiempo de almacenamiento de 24 horas y de 7 días en refrigeración. Se obtuvieron parámetros de calidad aceptables para el yogurt, preparado con una concentración del inóculo de $2 \%$, una temperatura de incubación de $40^{\circ} \mathrm{C}$ y un tiempo de incubación de 150 minutos. Además, se encontraron mejores propiedades de firmeza y de consistencia, con ausencia de sinéresis y viscosidad en el rango aceptado, para este producto lácteo.

Palabras clave: Acidez; Cultivo láctico; Sinéresis; Viscosidad; Yogur.

\section{INTRODUCTION}

Milk and dairy products have an important role in the human diet due to their many beneficial nutrients such as proteins, sugars, minerals, and water-soluble vitamins (Barkallah et al. 2017). Besides, dairy products, mainly fermented milk, are the most popular vehicles for supplementation and probiotics delivery in the human body due to their good compatibility, their pleasant and attractive sensory profile, and their high consumption worldwide (Heydari et al. 2018). Furthermore, in all its derivatives presentations that include low-fat yogurts, probiotics, smoothies, firm, ice cream, yogurt mousse (Casarotti et al. 2014; Ramírez \& Ruiz, 2014), several health benefits such as anticarcinogenic and anti-infection effects are offered, improving immune system, cholesterol reduction, relief of lactose intolerance and/or reduction of antibiotic side effects in the consumer (Heydari et al. 2018). The essential microorganisms used in the production of yogurt are Lactobacillus delbrueckii subsp. bulgaricus and Streptococcus thermophilus (Pancar et al. 2016) as well as bifidobacteria which are bacterial species considered as possible probiotics (Panesar \& Shinde, 2012; Kailasapathy, 2006). The latter are live microorganisms that if they are administered in adequate amounts, they provide health benefit on the host (Hill et al. 2014).

The traditional yogurt manufacturing process is mainly based on the microbial acidification of milk, due to lactic acid bacteria, which feed on milk lactose, generating lactic acid. Consequently, they reduce the $\mathrm{pH}$ of the milk to 4.5 , reaching the isoelectric point of the protein (casein), which coagulates, and yogurt is obtained (Vera \& Rodríguez, 2013) with its lactic flavor and typical aroma (Andrade et al. 2010). The acidification stage is the one that demands more time; therefore, accelerating the fermentation process would allow increasing the production capacity (Sahan $e t$ al. 2008; Vera \& Rodríguez, 2013). However, there are other factors that influence on this such as milk composition, dry matter, heating, homogenization, type of initial culture, incubation temperature, final fermentation $\mathrm{pH}$, cooling, storage time, among others (Kücükcetin, 2008). One of the most important attributes in yogurt is texture or firmness because it determines the quality and approval of the product. Thus, proper firmness without syneresis is essential to obtain a higher quality yogurt (Joon et al. 2017). Likewise, yogurt can have two main defects: variation in viscosity and spontaneous separation of whey that appears on the surface of yogurt (syneresis) (Hematyar et al. 2012); the latter situation is associated with the manufacture of industrial yogurt causing the loss of water from the yogurt gel (Pancar et al. 2016).

One of the most important aspects of this study is the use of lactic acid bacteria, which plays an essential role in yogurt manufacture. Therefore, if the inoculum level is increased in the presence of enough substrate, acidification occurs in less time (Vera \& Rodríguez, 2013). For this investigation semi-skimmed (2.6\%) and fat-free $(0 \%)$ milk are used for the yogurt process considering that several studies indicate that the fat content of yogurt alters its rheological and sensory characteristics (Sandoval-Castilla et al. 2004). This fact is due to that in the structuring process, fatty globules interact with the protein network that acts as protein binding agents (SandovalCastilla et al. 2004). Hence, low-fat and fat-free dairy products exhibit a weak body, poor texture and therefore whey separation as the total fat and solid contents are reduced (Delikanli \& Ozcan, 2014). In the same way, different levels of inoculum are established to evaluate the reduction of the fermentation time. Thus, the temperature, which is a very important factor, must be considered. The genus Streptococcus has an optimal growth between 42 and $45^{\circ} \mathrm{C}$ and Lactobacillus between 40 and $43^{\circ} \mathrm{C}$, considering that they act in symbiosis and both stimulate each other. Investigations on the effect of different incubation temperatures $\left(37,40,43\right.$ and $\left.45^{\circ} \mathrm{C}\right)$ stated that it is possible to significantly reduce the fermentation time by increasing the temperature, taking into account that at temperatures greater than $45^{\circ} \mathrm{C}$ the lactic acid bacteria decrease their acidification power (Vera \& Rodríguez, 2013).

The purpose of this study was to evaluate and to compare the effect of the type of milk, lactic culture, fermentation time and incubation temperature on $\mathrm{pH}$, acidity, syneresis, viscosity and general acceptability in beaten yogurt under refrigerated storage conditions.

\section{MATERIALS AND METHODS}

Materials. skim milk with 0\% fat and semi-skim milk with 2.6\% fat were used. The stock solution used for the preparation of yogurt contained the microorganisms L. bulgaricus, S. thermophilus, and probiotic culture $L$. casei and $L$. acidophilus.

Yogurt preparation. fresh and pasteurized milk (fat percentages of 0 and 2.6) were subjected to a thermal process to reach $30^{\circ} \mathrm{C}$ and then, sugar $(10 \% \mathrm{w} / \mathrm{w})$ was added. Subsequently, the mixture was homogenized at higher temperature $\left(36\right.$ and $40^{\circ} \mathrm{C}$ for each combination) and inoculated with stock culture (2 and $2.5 \%)$. At the end of the inoculation the samples were incubated for a period of $120 \mathrm{~min}$ and $150 \mathrm{~min}$ (at temperatures of 36 and $40^{\circ} \mathrm{C}$ ). At the end of the incubation, the yogurt was stored at $4^{\circ} \mathrm{C}$ for 7 days. The analyses were performed at the end of the incubation, at $24 \mathrm{~h}$ and 7 days after cooling $\left(\right.$ at $\left.4^{\circ} \mathrm{C}\right)$ in the Laboratory of Agroindustrial Biotechnology of the Instituto Universitario de la Paz, UNIPAZ. 
Physicochemical analysis. the $\mathrm{pH}$ values of the samples were measured using a pH meter (HACH HQ11d, Loveland, Colorado, U.S.A.) previously calibrated. The titratable acidity of yogurt was determined by taking a $10 \mathrm{~mL}$ sample of yogurt and holder with $0.1 \mathrm{~N}$ of $\mathrm{NaOH}$ using $1 \%$ phenolphthalein as an indicator until a weak pink color is obtained. Titratable acidity was calculated as $\%$ lactic acid (\% w/v) (Horwitz, 2000) using equation 1.

$$
\% \text { Lactic Acid }=\left(\frac{\mathrm{V} * \mathrm{~N} * 0,09}{\mathrm{~m}_{\mathrm{s}}}\right) * 100
$$

equation 1

Where $\mathrm{V}$ is the volume of $\mathrm{NaOH}$ spent, $\mathrm{N}$ is the normal concentration of $\mathrm{NaOH}$ used $(0.01 \mathrm{~N})$ and $\mathrm{m}_{\mathrm{s}}$ is the mass of the yogurt sample used.

The density was determined by a gravimetric method using glass pycnometers where the empty pycnometer, pycnometer with distilled water and the pycnometer with yogurt are weighed, and the density value is obtained with equation 2 :

$\rho_{\text {yogurt }}=\frac{\text { Weight }_{\text {pic }+ \text { yogurt }- \text { Weight }_{\text {empty pic }}}}{\text { Weight } \text { pic }_{\text {water }}-\text { Weight }_{\text {empty pic }}}$

equation 2

Total soluble solids were found using a manual refractometer (BRIXCO INSTRUMENTS, 0-90\%) (AOAC, 1998).

Syneresis assay: the syneresis was determined at 120 and $150 \mathrm{~min}$ of incubation and at $24 \mathrm{~h}$ and 7 days of yogurt incubation through the method of Cárdenas et al. (2013): $10 \mathrm{~g}$ of sample were put in a centrifuge tube that was centrifuged at $5000 \mathrm{rpm}$ for $20 \mathrm{~min}$. The supernatant weight was used to calculate the percentage of syneresis employing equation 3:

$$
\text { Syneresis }=\frac{\text { supernatant weight }}{\text { Sample weight }} * 100
$$

equation 3

Flow behavior. the Brookfield DV-I digital viscosimeter (Brookfield Engineering Laboratories Inc., Massachusetts, U.S.A.) was used to determine the rheological parameters. Measurements were made at different shear rates of 50 to $100 \mathrm{rpm}$ using $350 \mathrm{~mL}$ of the product stored at different storage times ( $24 \mathrm{~h}$ and 7 days) and incubation times (120, $150 \mathrm{~min})$. The samples were placed in $400 \mathrm{~mL}$ glasses, and the HA / HB-2 needle was used in all systems.

Experimental design. the experimental design was established to analyze the interactions between the dependent variables and to understand the phenomenon under study. In this way, a multivariate arrangement was made $2^{\mathrm{k}}=$ treatments $\left(2^{4}\right)$ using two levels (minimum and maximum) and four factors $(\mathrm{k})$ corresponding to $\%$ fat (A), \% starter culture (B), incubation temperature (C), incubation time (D) (Table 1). Statistical analysis was performed using Minitab software version 17 (State College, Pennsylvania, U.S.A), using a level of significance of $\mathrm{P}<0.05$ for the analysis of variance (ANOVA). All physicochemical analyzes were performed in triplicate and the results were expressed as the average of the data. The entire methodological procedure was carried out under a strict sterilization protocol to avoid possible cross contamination and unwanted microbiological growths.

\begin{tabular}{|c|c|c|c|c|}
\hline & Factors & & Levels & Variable response \\
\hline \multirow{2}{*}{ A) } & \multirow{2}{*}{ Fat content } & \multicolumn{2}{|r|}{$0 \%(-)$} & \multirow{8}{*}{$\begin{array}{l}\mathrm{pH} \text { of the final product - fermented milk } \\
\text { beverage - Yogurt }\end{array}$} \\
\hline & & & $2.6 \%(+)$ & \\
\hline \multirow{2}{*}{ B) } & \multirow{2}{*}{ Inoculum concentration } & & $2 \%(-)$ & \\
\hline & & & $2.5 \%(+)$ & \\
\hline \multirow{2}{*}{ C) } & \multirow{2}{*}{ Incubation Temperature } & \multicolumn{2}{|r|}{$36{ }^{\circ} \mathrm{C}(-)$} & \\
\hline & & \multicolumn{2}{|r|}{$40{ }^{\circ} \mathrm{C}(+)$} & \\
\hline \multirow{2}{*}{ D) } & \multirow{2}{*}{ Incubation Time } & \multicolumn{2}{|r|}{$120 \min (-)$} & \\
\hline & & \multicolumn{2}{|r|}{$150 \min (+)$} & \\
\hline \multirow{2}{*}{\multicolumn{2}{|c|}{ Treatment }} & \multicolumn{3}{|r|}{ Factor } \\
\hline & & $\mathbf{A}$ & B & $\mathbf{D}$ \\
\hline & T1 & - & - & - \\
\hline & $\mathrm{T} 2$ & + & - & - \\
\hline & T3 & - & + & - \\
\hline & $\mathrm{T} 4$ & + & + & - \\
\hline
\end{tabular}

Table 1. Experimental design. 
Continuación Tabla 1

\begin{tabular}{|c|c|c|c|c|}
\hline T5 & - & - & + & - \\
\hline T6 & + & - & + & - \\
\hline T7 & - & + & + & - \\
\hline T8 & + & + & - & + \\
\hline T9 & - & - & - & + \\
\hline T10 & + & - & - & + \\
\hline T11 & - & + & + & + \\
\hline T12 & + & + & + & + \\
\hline T13 & - & - & + & + \\
\hline
\end{tabular}

The significant effects are A:\% Fat; C: $\mathrm{T}^{\circ} \mathrm{C}$ Incubation; AxC: $\%$ Fat Vs. $\mathrm{T}^{\circ} \mathrm{C}$ Incubation; CxD: $\mathrm{T}^{\circ} \mathrm{C}$ Incubation Vs. Incubation Time; AxBxD: \% Fat Vs. \% Culture Vs. $\mathrm{T}^{\circ} \mathrm{C}$ Incubation; AxBxCxD: \% Fat Vs. $\%$ Culture Vs. $\mathrm{T}^{\circ} \mathrm{C}$ Incubation Vs. Incubation Time.

\section{RESULTS AND DISCUSSION}

Physicochemical analysis. Figure 1 and 2 show the variation in $\mathrm{pH}$ and acidity from the end of the incubation period and during the storage period ( $24 \mathrm{~h}$ and 7 days), for each fat content of the milk.

The behavior of $\mathrm{pH}$ and acidity of the yogurt measured $24 \mathrm{~h}$ after stored at $4^{\circ} \mathrm{C}$ (Figure 1) does not follow a clear tendency, which determines that there must be a different factor than those studied which directly affects this variation in $\mathrm{pH}$.

On the other hand, the acidity maintains an increasing behavior except for the case of skim milk with an incubation time of 120 min, due to the lower conversion of lactose, possibly time was not enough for the proper fermentation process. In comparison with the data obtained just at the end of the incubation, there is no definite

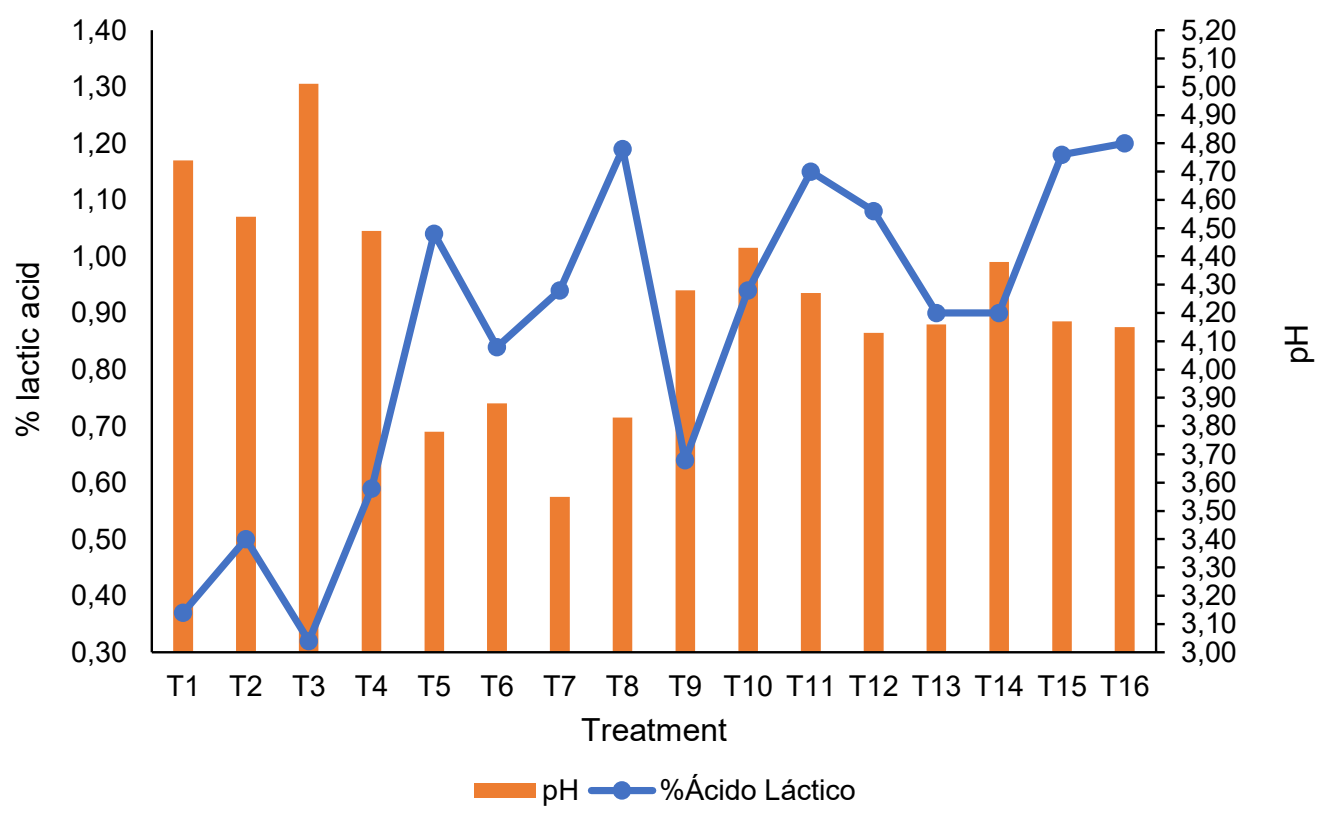

Figure 1. $\mathrm{pH}$ (bars) and acidity (red lines) of yogurt treatments measured after $24 \mathrm{~h}$ of incubation $(\mathrm{n}=3)$. 


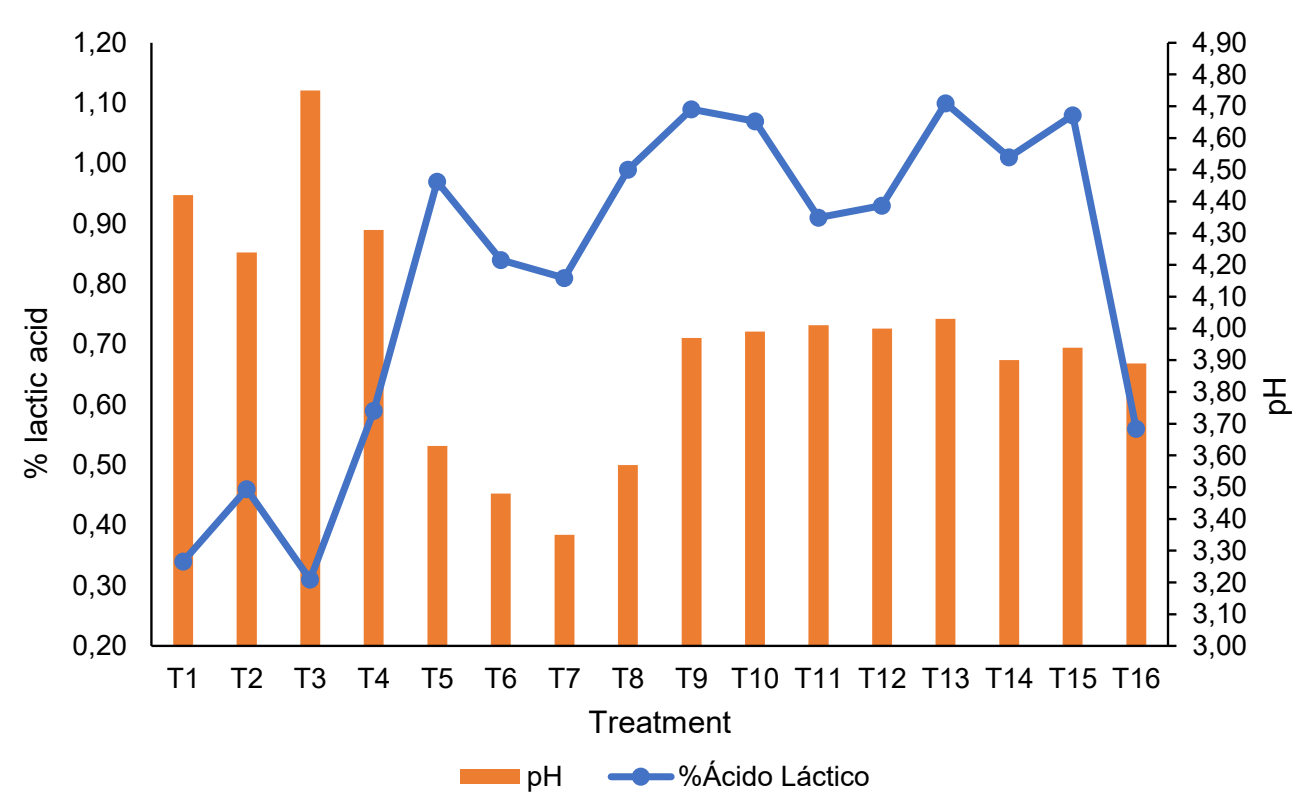

Figure 2. $\mathrm{pH}$ (bars) and acidity (red lines) of yogurt treatments measured after 7 days in storage $(\mathrm{n}=3)$.

trend that allows concluding some effect between the storage time and the $\mathrm{pH}$ of the yogurt. The treatments $\mathrm{T} 5$ to $\mathrm{T} 8$, in which the $\mathrm{pH}$ increases $24 \mathrm{~h}$ after the end of the incubation, and the treatments $\mathrm{T} 9$ to $\mathrm{T} 16$, where the $\mathrm{pH}$ decreases, stand out from the rest.

The tendency to decrease the $\mathrm{pH}$ can be attributed to both the activity of beneficial and harmful microorganisms. The latter can lead to a decrease in $\mathrm{pH}$ due to the consumption of sugar and the production of organic acids. When the sugar resources are finished, microorganisms consume proteins from the environment, and this will increase the $\mathrm{pH}$ as investigated by Shahbandari et al. (2016). Also, in general acidity shows an increasing tendency in all treatments, 24 $\mathrm{h}$ after finished the incubation process.

Figure 2 shows the samples behavior after 7 days of storage under refrigeration conditions. The reduction in $\mathrm{pH}$ and the increase in the total acidity of yogurts during storage could possibly be explained due to the increased consumption of residual lactose by lactic acid bacteria (Curti et al. 2017).

Other studies reported that the $\mathrm{pH}$ of yogurt decreased during storage under refrigeration conditions between 3.8 and 4.5 (Olson $\&$ Aryana, 2008). The reduction in the $\mathrm{pH}$ of yogurt may be due to the degradation of lactose in lactic acid (Hassan \& Amjad, 2010). Considering the experiments carried out, the best working variables were selected: temperature $\left(40^{\circ} \mathrm{C}\right)$, incubation time $(150 \mathrm{~min})$ and inoculum concentration $(2 \%)$, with a refrigeration storage period of 7 days.

In the present investigation the variables that most affect the response variable $(\mathrm{pH})$ are the incubation time $(\mathrm{D})$ and the incubation temperature $(\mathrm{C})$; especially the combination of incubation temperature with incubation time. The best treatment, to maintain a $\mathrm{pH}$ up to 4.5 after $24 \mathrm{~h}$ and 7 days of incubation, would be an incubation temperature of $40^{\circ} \mathrm{C}$ and incubation time of $150 \mathrm{~min}$.

Although the variables of $\%$ fat and $\%$ inoculum do not significantly affect the response variables as shown by the Pareto chart (Figure 3 ), the normal graph and the $\mathrm{p}$ values (which for these two variables are greater than $\alpha=0.05(\mathrm{p}>0.05)), \mathrm{a} \%$ fat of $0 \%$ and an inoculum concentration of $2 \%$ are recommended.

Syneresis behavior: syneresis is an appreciable defect briefly, due to the appearance of two phases, whey, and water. Among the main causes of this behavior are low milk quality, very high incubation temperature, low acidity, enzymes that clot the protein and low viscosity. In this study, the consistency and stability of yogurt were analyzed through the calculation of syneresis. On treatments T1, $\mathrm{T} 2, \mathrm{~T} 3, \mathrm{~T} 9, \mathrm{~T} 10, \mathrm{~T} 11$, and $\mathrm{T} 12$ there was no syneresis in any of the samples. The results of syneresis converge as in the physicochemical analysis, in which the optimal working factors are $2 \%$ of the stock culture and incubation temperature $40^{\circ} \mathrm{C}$.

Figure 4 shows the results for the other treatments where the highest point of syneresis was obtained in the T13 treatment corresponding to $0 \%$ fat milk, $2 \%$ stock culture, incubation temperature $40^{\circ} \mathrm{C}$ and incubation time $150 \mathrm{~min}$. At incubation temperature of $40^{\circ} \mathrm{C}$, a trend is revealed, at a shorter incubation time, the quality of yogurt would be better after 7 days in storage.

The syneresis values may increase as the $\mathrm{pH}$ decreases because the yogurt continues to produce lactic acid during storage (Rebollar, 2017), it should be mentioned that the $\mathrm{pH}$ of treatment 13 ranges by 4.2 and may affect the stability of the structural network of the 


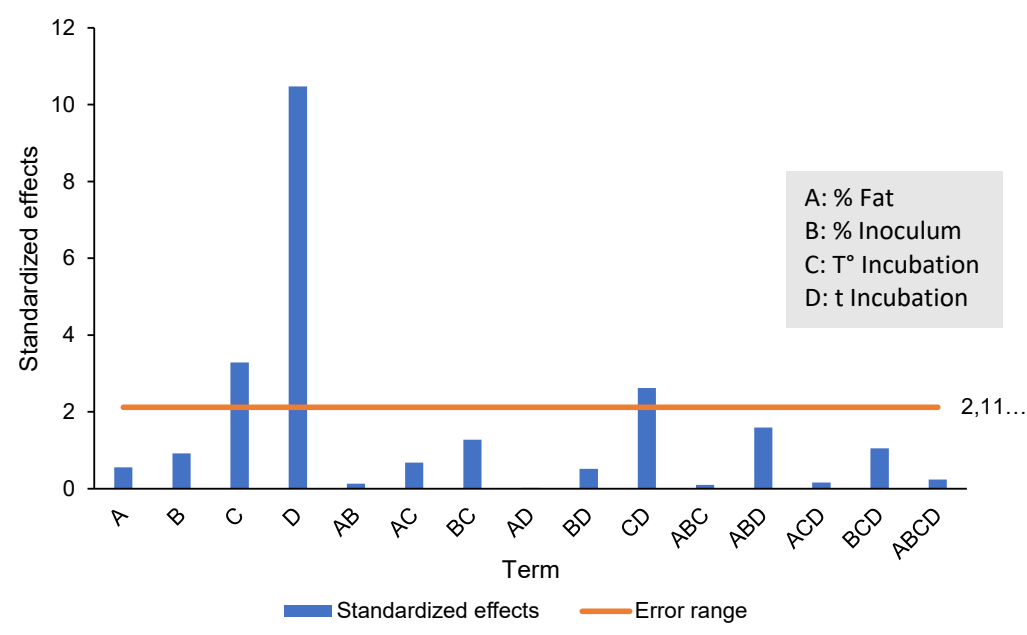

Figure 3. Pareto Chart of the Standardized Effects. (response is $\mathrm{pH} ; \alpha=0,05$ ).

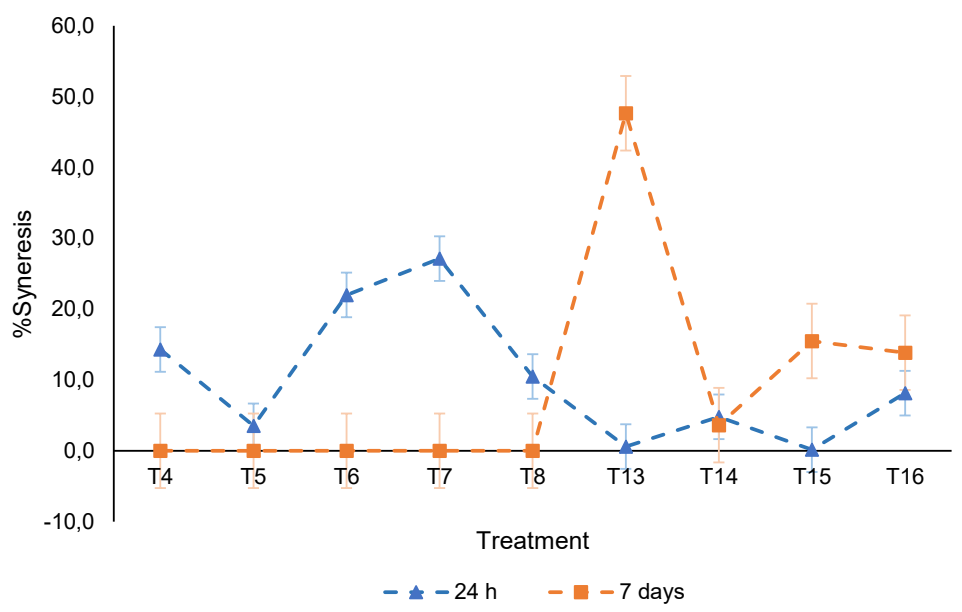

Figure 4. Syneresis of yogurt with $24 \mathrm{~h}$ and 7 days of storage.D.

yogurt. According to Lucey \& Singh (1997), casein aggregation occurs at the isoelectric point $(\mathrm{pH}=4.6)$ because of the repulsion between micelles decreases; at this point, the contraction of the structural network results in the whey release. According to the results, the isoelectric point of casein studied in this work is below the $\mathrm{pH}$ range of fermented beverages, this explains the syneresis values found in figure 3 .

Figure 5 shows the apparent viscosity of the samples of yogurt stored at different times. A higher incubation time (150 min) of the yogurt led to an increase of the apparent viscosity at high rotation speed (graphs a and c), while a pseudoplastic behavior is observed in graphs $\mathrm{b}$ and $\mathrm{d}$ for treatments at 120 min incubation time.
Viscosity values of yogurt samples are affected by several factors: composition, starter cultures, heat treatment (Velez-Ruiz et al. 2012; Mohan et al. 2020). Likewise, as the total solids increase (e.g. fat content), the viscosity and firmness of the yogurt increase (Tarrega et al. 2016).

Semi-skimmed milk $(2.6 \%)$ and fat-free $(0 \%)$ for the yogurt process showed variations in $\mathrm{pH}$ and acidity as well as in its texture and firmness structure. This may be due to various studies indicating that the fat content of yogurt alters its rheological and sensory characteristics as in the structuring process, fatty globules interact with the protein network that acts as protein-binding agents. Therefore, low-fat and fat-free dairy products exhibit a weak body, 

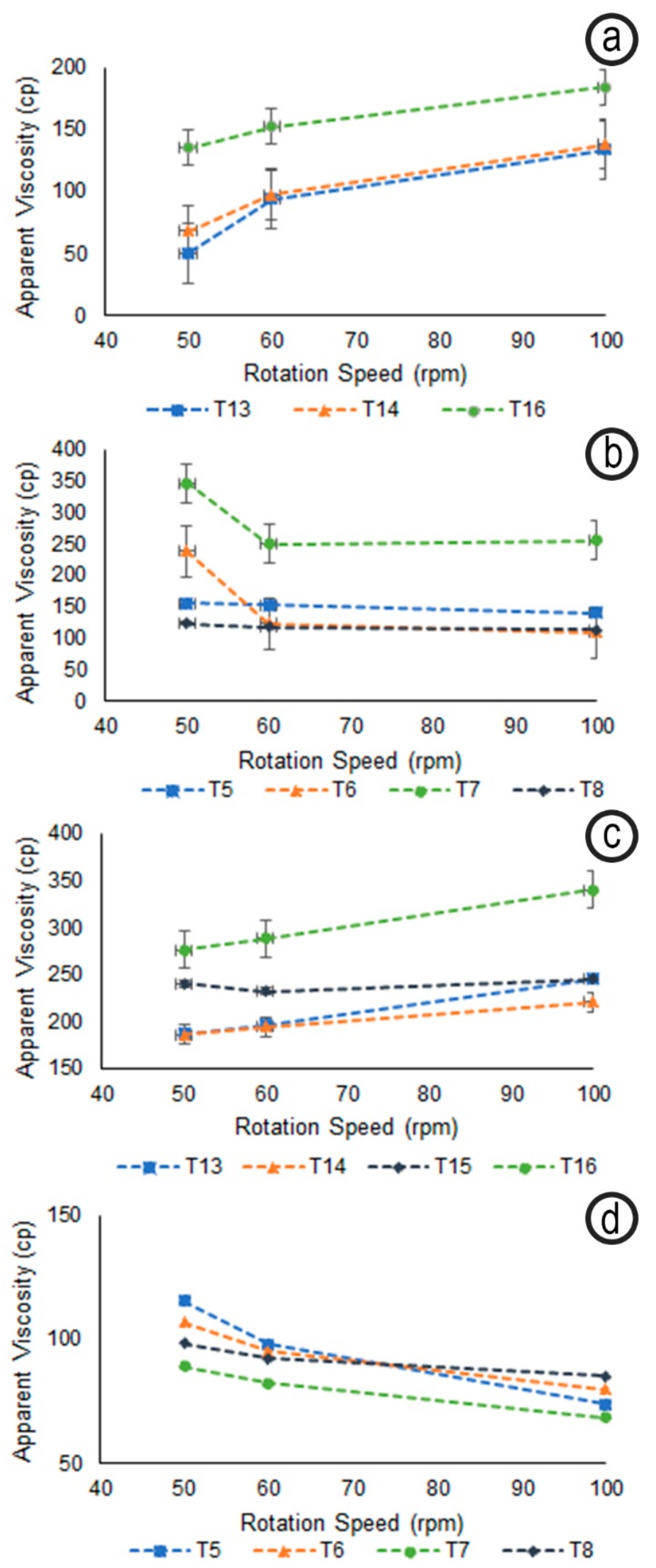

Figure 5. Viscosity behavior at different rotation speeds for yogurt stored for $24 \mathrm{~h}$ (a and b) and 7 days (c and d). 
poor texture and, therefore, whey separation as the total fat and solid contents are reduced.

The variables for the preparation of yogurt were: $40^{\circ} \mathrm{C}$ incubation temperature, 150 min incubation time and $2 \%$ stock culture, as they did not show syneresis; $\mathrm{pH}$ and acidity values were found in the acceptable ranges and the best properties of consistency and firmness were obtained, after 7 days in storage at $4^{\circ} \mathrm{C}$.

\section{REFERENCES}

1. ANDRADE, R.D.; ARTEAGA, M.R.; SIMANCA, M.M. 2010. Efecto del Salvado de Trigo en el Comportamiento Reológico del Yogurt de Leche de Búfala. Información tecnológica (Chile). 21(5):117-124.

https://dx.doi.org/10.4067/S0718-07642010000500015

2. ASSOCIATION OF OFFICIAL ANALYTICAL CHEMISTS, AOAC. 1998. Official Methods of Analysis, 15th ed. Washington DC (USA).

3. BARKALLAH, M.; DAMMAK, M.; LOUATI, I.; HENTATI, F.; HADRICH, B.; MECHICHI, T.; AYADI, M.A.; FENDRID, I.; ATTIA, H.; ABDELKAFIA, S. 2017. Effect of Spirulina platensis fortification on physicochemical, textural, antioxidant and sensory properties of yogurt during fermentation and storage. LWT - Food Science and Technology (England). 84:323-330.

https://doi.org/10.1016/j.lwt.2017.05.071

4. CÁRDENAS C., A.; ALVITES G., H.; VALLADARES C., G.; OBREGÓN, J.; VÁSQUEZ-VILLALOBOS, V. 2013. Optimización mediante diseño de mezclas de sinéresis y textura sensorial de yogurt natural batido utilizando tres tipos de hidroloides. Revista Cientifica de la Universidad Nacional de Trujillo. Agroindustrial Science (Perú). 3(1):3540 .

http://dx.doi.org/10.17268/agroind.science.2013.01.04

5. CASAROT'TI, S.N.; MONTEIRO, D.A.; MORETTI, M.M.S.; PENNA, A.L.B. 2014. Influence of the combination of probiotic cultures during fermentation and storage of fermented milk. Food Research International (USA). 59:6775 .

https://doi.org/10.1016/j.foodres.2014.01.068

6. CURTI, C.A.; VIDAL, P.M.; CURTI, R.N.; RAMÓN, A.N. 2017. Chemical characterization, texture and consumer acceptability of yogurts supplemented with quinoa flour. Food Science and Technology (Brasil). 37(4):627-631. http://dx.doi.org/10.1590/1678-457x.27716

7. DELIKANLI, B.; OZCAN, T. 2014. Effects of various whey proteins on the physicochemical and textural properties of set type nonfat yoghurt. International Journal of Dairy Technology (England). 67(4):495-503.

https://doi.org/10.1111/1471-0307.12142

8. HASSAN, A.; AMJAD, I. 2010. Nutritional evaluation of yoghurt prepared by different starter cultures and their physiochemical analysis during storage. African Journal of Biotechnology (Kenya). 9(20):2913-2917. https://doi.org/10.5897/AJB2010.000-3121

9. HEMATYAR, N.; MOHAGHEGHI S., A.; POORAZARANG, H.; HOSSEIN E., A. 2012. Effect of Gums on Yogurt Characteristics. World Applied Sciences Journal (Pakistan). 20(5):661-665.

https://doi.org/10.5829/idosi.wasj.2012.20.05.2353

10. HEYDARI, S.; AMIRI-RIGI, A.; EHSANI, M.R.; MOHAMMADIFAR, M.A.; KHORSHIDIAN, N.; KOUSHKI, M.R.; MORTAZAVIAN, A.M. 2018. Rheological behaviour, sensory properties and syneresis of probiotic yoghurt supplemented with various prebiotics. International Journal of Dairy Technology (England). 71(S1):175-184. https://doi.org/10.1111/1471-0307.12491

11. HILL, C.; GUARNER, F.; REID, G.; GIBSON, G.R.; MERENSTEIN, D.J.; POT, B.; MORELLI, L.; CANANI, R.B.; FLINT, H.J.; SALMINEN, S.; CALDER, P.C.; SANDERS, M.E. 2014. Expert consensus document. The International Scientific Association for Probiotics and Prebiotics consensus statement on the scope and appropriate use of the term probiotic. Nature Reviews Gastroenterology \& Hepatology (USA). 11(8):506-14. https://doi.org/10.1038/nrgastro.2014.66

12. HORWITZ, W. 2000. Official Methods of Analysis, 17th ed. Gaithersburg (USA).

13. JOON, R.; KUMAR M., S.; SINGH B., G.; KUMAR S., P.; PANWAR, H. 2017. Instrumental texture and syneresis analysis of yoghurt prepared from goat and cow milk. The Pharma Innovation Journal (India). 6(7):971-974.

14. KAILASAPATHY, K. 2006. Survival of free and encapsulated probiotic bacteria and their effect on the sensory properties of yoghurt. LW'T - Food Science and Technology (England). 39(10):1221-1227. https://doi.org/10.1016/j.lwt.2005.07.013

15. KÜCÜKCETIN, A. 2008. Effect of heat treatment of skim milk and final fermentation $\mathrm{pH}$ on graininess and roughness of stirred yogurt. International Journal of Dairy Technology (United Kingdom). 61(4):385-390. https://doi.org/10.1111/j.1471-0307.2008.00420.x 
16. LUCEY, J.A.; SINGH, H. 1997. Formation and physical properties of acid milk gels: a review. Food Research International (USA). 30(7):529-42.

https://doi.org/10.1016/S0963-9969(98)00015-5

17. MOHAN, A.; HADI, J.; GUTIERREZ-MADDOX, N.; LI, Y; LEUNG, I.K.H.; GAO, Y.; SHU, Q.; QUEK, S. 2020. Sensory, Microbiological and Physicochemical Characterisation of Functional Manuka Honey Yogurts Containing Probiotic Lactobacillus reuteri DPC16. Foods. 9(1):1-17. https://doi.org/10.3390/foods9010106

18. OLSON, D.W.; ARYANA, K.J. 2008. An excessively high Lactobacillus acidophilus inoculation level in yogurt lowers product quality during storage. LWT - Food Science and Technology (England). 41(5):911-918. https://doi.org/10.1016/j.lwt.2007.05.017

19. PANCAR, E.D.; ANDIÇ, S.; BORAN, G. 2016. Comparative Effects of Fish and Cow Gelatins and Locust Bean Gum on Chemical, Textural, and Sensory Properties of Yogurt. Journal of Aquatic Food Product Technology (USA). 25(6):843-853.

http://dx.doi.org/10.1080/10498850.2014.944293

20. PANESAR, P.S.; SHINDE, C. 2012. Effect of Storage on Syneresis, $\mathrm{pH}$, Lactobacillus acidophilus count, bifidobacterium bifidum count of Aloe vera fortified probiotic yoghurt. Current Research in Dairy Sciences (Pakistan). 4(1):17-23. http://dx.doi.org/10.3923/crds.2012.17.23

21. RAMÍREZ M., A.O.; RUIZ R., J.A. 2014. Elaboración de yogurt firme bajo en calorías con inulina y harina de guayaba (Psidium guajava L.) como saborizante. Revista de la Facultad de Agronomía de la Universidad del Zulia (Venezuela). 31(2):233-252.

22. REBOLLAR, T. 2017. Características fisicoquímicas y sensoriales de yogurt natural elaborado artesanalmente. Universidad Autónoma Agraria Antonio Narro. 1-69p.
23. SAHAN, N.; YASAR, K.; HAYALOGLU, A.A. 2008. Physical, chemical and flavour quality of non-fat yogurt as affected by a $\beta$ - glucan hydrocolloidal composite during storage. Food Hydrocolloids (USA). 22(7):1291-1297. https://doi.org/10.1016/j.foodhyd.2007.06.010

24. SANDOVAL-CASTILLA, O.; LOBATO-CALLEROS, C.; AGUIRRE-MANDUJANO, E.; VERNON-CARTER, E.J. 2004. Microstructure and texture of yogurt as influenced by fat replacers. International Dairy Journal (England). 14(2):151-159. https://doi.org/10.1016/S0958-6946(03)00166-3

25. SHAHBANDARI, J.; GOLKAR, A.; TAGHAVI, S.M.; AMIRI, A. 2016. Effect of Storage Period on Physicochemical, Textural, Microbial and Sensory Characteristics of Stirred Soy Yogurt. International Journal of Farming and Allied Sciences (Pakistan). 5(6):476-484.

26. TARREGA, A.; MARCANO, J.; FISZMAN, S. 2016. Yogurt viscosity and fruit pieces affect satiating capacity expectations. Food Research International. 89:574-581. https://doi.org/10.1016/j.foodres.2016.09.011

27. VELEZ-RUIZ, J.F.; HERNANDEZ-CARRANZA, P.; SOSAMORALES, M. 2012. Physicochemical and flow properties of low-fat yogurt fortified with calcium and fiber. Journal of Food Processing and Preservation (USA). 37(3):1-12. https://doi.org/10.1111/j.1745-4549.2011.00638.x

28. VERA B., R.; RODRÍGUEZ Z., A. 2013. Efecto de la adición de caseinato de sodio y gelatina sobre la viscosidad, sinéresis y tiempo de fermentación en yogurt batido. Pueblo Continente (Perú). 24(1):133-140. 